\title{
Comparison of relationship perception in the international fresh produce business
}

Amos Gyau and Achim Spiller

Department of Agricultural Economics and Rural Development, University of Göettingen, Göettingen, Germany

\begin{abstract}
Purpose - The suppliers of fresh fruit and vegetable complain that their buyers in the retail segment of the market used certain undesirable and questionable business practices which are not used by buyers in other segments. These undesirable practices may have negative effects on how the exporters perceive their relationship with the retailers compared with how they will perceive the non-retail buyers. This paper aims to compare the perceived relationship quality of the retailer group of buyers with the buyers in the other categories of the fresh fruit and vegetable business between Ghana and Europe.

Design/methodology/approach - Using the literature on inter-firm relationships as a basis, a structured questionnaire was designed and administered to 101 exporters in Ghana. Multivariate analysis of variance (MANOVA) procedure and post hoc test were used to determine the differences in the perceived relationship quality of the exporters classified according to their main European buyer type.

Findings - The empirical results from the study support the hypotheses that exporters have a lower perception of the quality of their relationship with retailers compared with the wholesalers and the food service firms. In addition, whereas differences in exporters' experience were observed depending on the type of European importer to whom they mainly sell, the size of the exporters does not differ. The paper concludes that, in the context of the fresh produce business, the level of perceived power exploitation may differ depending on the type of business organisation or the position of the firm in the supply chain.

Originality/value - It is recommended that export firms need to examine the category to which their main buyer belongs before they make relationship-specific investments. The results also provide a guide for policy makers and antitrust bodies in the various European countries to be able to effectively target their policies to address unfair business practices.
\end{abstract}

Keywords Buyer-seller relationships, Exports, Imports, Fruits, Vegetables

Paper type Research paper

\section{Introduction}

\section{Background and justification}

In the international fresh fruit and vegetable (FFV) trade, various categories of buyers can be identified. These include retailers, wholesalers, food service firms and the processing companies. Exporters of FFV often complain that the buyers in the retail categories use several questionable business practices in their dealings (Patterson and Richards, 2000; Dobson, 2005). These include collection of slotting fees from the suppliers, pay-to-stay, promotional allowances, failure fees and host of other ways in which retailers demand payment from suppliers in order to stock their products, allocate certain amount of space on their shelves for the suppliers' products and to help promote the suppliers' products (Food Institute, 1999). These practices enable the 
JEIM

22,4

442

retailers to maximize their own efficiency and profitability by passing problems and costs down the supply chain to the suppliers.

Dobson (2005) attributed the retailers' ability to resort to the practices described above mainly to asymmetric power relations in which the retailers are the more powerful parties. The retailers' power source according to Dobson (2005) may stem from the fact that they sell different assortment of product (typically 20,000-30,000 different products) compared to the firms in the other categories who may rely on relatively fewer product lines. The retailers, thus, may be less dependent on their suppliers than a specialized wholesaler or the firms in the food service industry, since business with a particular supplier will constitute a smaller percentage of the retailers' total business compared to the other group of buyers.

Since a number of authors such as Gummesson (1996); Kumar (1996); Kumar et al. (1998) and Rokkan and Haughland (2002) have argued that power symmetry in relationships improve relationship quality whilst asymmetric relationships hamper relationship quality, it can be hypothesized that retailers are likely to be evaluated worse by their suppliers in terms of relationship quality compared to buyers in the other categories. This is mainly because there is little or no evidence of such questionable business practices executed by the wholesalers and the food service firms.

Relationship quality is an important variable to maintain business relationships, as has been shown by a number of researchers (Wray et al., 1994; Kim and Cha, 2002; Kim et al., 2006; Schulze et al., 2006; Gyau and Spiller, 2007a). However, despite the strong hints for differences in the business practices of the retailers compared to the buyers in the other categories, to our knowledge there is no research to date that explicitly compares the perceived relationship quality of the suppliers although these practices may have implication on relationship quality. The aim of this contribution is to fill this gap in the literature by comparing the perception of the exporters' relationship quality in their dealings with retailers, wholesalers and firms in the food service industry.

The remaining sections of the paper are organised as follows: in the second part of this section, we provide an overview of the FFV trade between Ghana and Europe. Section two is dedicated to the literature review on relationship quality and inter-firm power. In the third and the fourth sections, we state our hypotheses and present a detailed account of the data collection process and statistical analysis respectively. The fifth section is dedicated to the findings of the study where we report and discuss the results of the statistical analysis. In section six, we provide managerial and policy implications of the study. Conclusions and directions for future research are discussed in section seven.

Distribution channel of the fresh fruit and vegetable trade between Ghana and Europe Fresh fruits and vegetables like pineapples, mangoes, papaya, chilli, eggplant and other Asian vegetables are exported from Ghana into Europe. In Figure 1, we provide a simplified distribution channel of the FFV supply chain between Ghana and Europe. Takane (2004) distinguished between three main types of growers as smallholder farmers, non-resident commercial farmers and large-scale producer exporters. The smallholder farmers are individuals who produce relatively smaller quantities of fruit and vegetables. This group of farmers is made up of indigenous people in farming communities who produce and sell mainly to the local market and the Ghanaian 
processing companies. In recent years, these farmers have formed cooperatives that have enabled them to sell collectively in the European market.

The non-resident commercial farmers are those who acquire land and engage in commercial farming but do not usually live in the area where their farming activities take place (Takane, 2004). This group often produces on larger scale compared to the smallholders, and usually sells through produce marketing organisations (PMOs). The PMOs are specialized firms that market FFV. They do not usually operate farms but acquire their products mainly from the smallholders and the non-resident commercial farmers. The large-scale producer-exporters produce on large-scale and usually sell their products directly to Europe and to the Ghanaian processing companies.

FFV are sold either as a whole or sliced to retailers, wholesalers and the food service firms in Europe (PFID, 2003). The retailers are firms that sell directly to the final consumers. They include supermarkets, discount stores, hypermarkets, convenient shops and the various small shops such as African, Asian and Mexican shops who sell directly to the consumers. The food service industry is made up of firms that produce ready to eat food and includes hotels, big restaurants, catering firms and fast food operators.

The wholesalers consist of all the middlemen such as importers and distributors (including wholesale markets in this context) who serve as intermediaries between the exporters on the one hand and retailers and food-service industry on the other hand. There are various types of wholesalers involved in the FFV distribution channels. Prominent ones are the merchant wholesalers, the brokers otherwise called the commission agents and the sales branches of some exporters. In addition, certain retail groups also operate their own wholesale units that may supply to the various shops.

Hitherto, FFV was imported by specialized import firms that fall in the wholesale segment and sold to retailers and the food service industries in Europe. However, in recent years, some food service firms and retailers source directly from the exporters in developing countries. According to Fearne and Hughes (1999), this development may be attributed to the need for retailers to ensure the integrity of their own label products in terms of quality and safety, and also to reduce supply chain costs in an effort to increase their competitiveness in the retailing environment. Another reason is that it has become important for most firms to increase their reputations by ensuring that their products take into consideration social and environmental standards including the avoidance of use of child labour, environmental sustainability and fair wages. The processing companies located in Europe were not found to buy from the Ghanaian exporters.

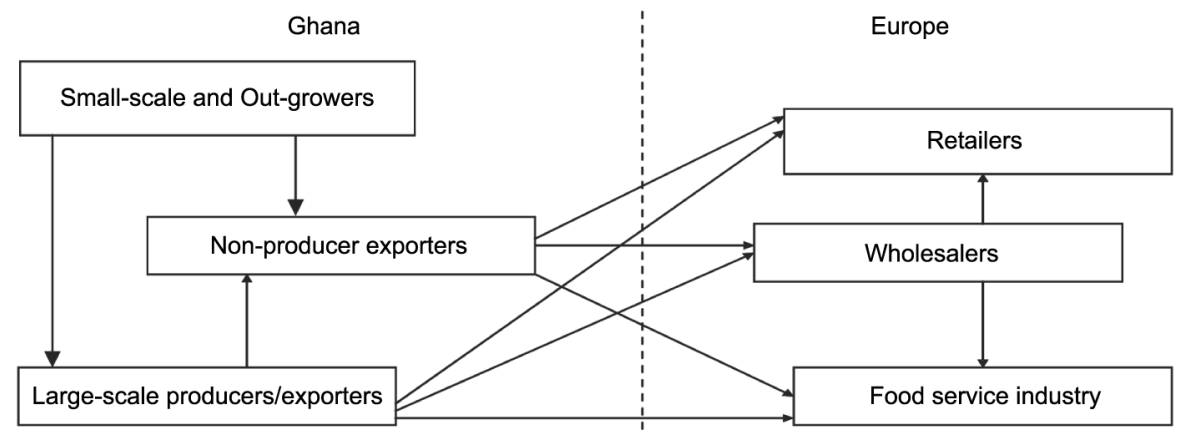

\section{Relationship perception}

443
Figure 1.

Distribution channel of fresh fruit and vegetable trade between Ghana and

Europe 
JEIM

22,4

444

\section{Literature review}

\section{Relationship quality}

In recent years, the concept of relationship marketing has rapidly emerged as one of the dominant paradigms of marketing (Baker, 1995), at a time when there is a general concern about choosing the most suitable and appropriate paradigm to guide the future development of long-term business relationships. Against this background, discussions on supply chain management have been more enriched by alternative approaches during the last decade (Ellram and Cooper, 1993; New, 1996). This was fuelled by the existence of different research streams in fields such as channel marketing, industrial marketing and consumer marketing. The implication is that the different research streams have used approaches that suit their interest to measure relationship quality, and there seems to be no consensus among researchers on the set of constructs or variables which constitute relationship quality, or what its antecedents are (Crosby et al., 1990).

Jarvelin and Lehtinen (1996) for instance, defined relationship quality as actors' perception of how well their relationships fulfil the expectations, predictions, goals and desires of their customers. According to Wong and Sohal (2002), relationship quality conveys actors' impression about the whole relationship and is manifested in several distinct but related constructs.

Crosby et al. (1990); Wray et al. (1994); Kim and Cha (2002); Kim et al. (2006) and Gyau and Spiller (2007a) operationalised relationship quality with satisfaction and trust in the supply chain. Leuthesser (1997), Dorsch et al. (1998), and Naudé and Buttle (2000) highlighted the relevance of trust, satisfaction, commitment, opportunism, customer satisfaction, and ethical profile in the measurement of relationship quality. Based on the above discussions, we recognise that the relationship quality is a higher order construct with numerous dimensions.

Notwithstanding the fact that researchers conceptualise relationship quality with different dimensions, they seem to generally agree on the fact that relationship quality measures actors' perceptions of how well their relationships with their partners are, and is often linked to firms' ability to sustain their relationships in a long-term. Ceceres and Paparoidamis (2007, pp. 837) stated that:

... there is general agreement in the relationship marketing literature that the quality of the relationship between the parties involved is an important determinant of the permanency and the intensity of the relationship and the consequent success of relationship marketing practices.

Relationship quality has been linked positively to partners' ability to build and maintain long-term and collaborative relationships through loyalty and commitment (Berry and Parasuraman, 1995; Garbarino and Johnson, 1999; Pritchard et al., 1999). This implies that firms that have good relationship quality would be perceived as more long-term oriented and vice versa.

For the purpose of this paper, relationship quality is conceptualised with trust, satisfaction and commitment. Trust is often considered as the critical determinant of good relationships (Dwyer et al., 1987; Ganesan, 1994; Morgan and Hunt, 1994; Gyau and Spiller, 2007b). Trust refers to the willingness to rely on an exchange partner in whom one has confidence (Moorman et al., 1992). Anderson and Narus (1990) viewed trust as the belief that a business partner will perform actions that will result in a positive outcome for the firm and not to take unexpected actions that may result in negative outcomes. Satisfaction refers to a positive affective state resulting from the 
appraisal of all aspects of a firm's working relation with another firm. Taking insights from the disconfirmation theory, satisfaction can be measured by comparison of a supplier's performance with buyer's expectation levels. Anderson and Narus (1990) indicated that satisfaction encourages long-term relationships. Ganesan (1994) argued that a higher level of satisfaction is an indication of improved relationship and vice versa. Commitment is defined as an exchange partner believing that an ongoing relationship with an exchange partner is so important as to warrant maximum efforts at maintaining it (Morgan and Hunt, 1994). Thus, the committed party believes that the relationship endures into the future.

\section{Power and relationship quality}

Power is the ability of one actor to influence another to act in a manner that he/she would not have otherwise (Emerson, 1962). Four main power structures have been identified in the literature namely: dominance, interdependence, independence and dependence (Cox et al., 2003). Thibaut and Kelly (1959) explore the issue of both coercive and constructive conflicts in personal relationships, and this was applied in business to business context by Ford (1994), who argued that all inter-organisational relationships exhibit conflicts and cooperation simultaneously and that the two are not mutually exclusive. Some authors such as Cox et al. (2003) argue that power should be at the centre of any study of buyer-seller relationships.

In relationship marketing, emphasis on the necessity for power symmetry and mutuality has been expressed. Gummesson (1996), Kumar (1996), Kumar et al. (1998), and Rokkan and Haughland (2002) for instance argued that symmetric dependence structures foster improved relationship quality while asymmetric relationships are associated with less stability and more conflicts and consequently hamper relationship quality. A section of the literature views the concept of power as a source of inefficient and ineffective exchange relationships where success is determined through the principle of cooperation and trust.

Anderson and Weitz (1989), Anderson and Narus (1990), Ganesan (1994), and Vadarajan and Cunningham (1995) pointed out that in a situation of power imbalance, the party with the higher level of power will try to exploit its advantage in such a way that the other party becomes dissatisfied with the relationship. The above implies that since the retailers have and exercise more buyer power compared to the buyers in the other categories, the retailers are more likely to be perceived to have a poorer relationship quality by the FFV exporters compared to the others. Porter (1980) has argued that in a situation of buyer concentration and availability of substitutes, buyer power will be high implying since the retailers sell much more different products which compete for shelve space, they are more likely to possess and exercise buyer power than the food service and the wholesalers.

\section{Hypotheses}

The hypotheses are based on the argument that the retailers' business practices exhibit relatively more use of power. However, such business practices have not been observed about the wholesalers and the food service firms. Since such business practices have implications on relationship quality, this implies that the retailers would be more poorly rated by exporters in terms of their business relationship quality compared to the wholesalers and the firms in the food service industry.

\section{Relationship perception}

445 
JEIM

22,4

446

Specifically, we test the following hypotheses:

H1. The FFV exporters' perception of business relationship quality for retailers is lower than wholesalers.

H2. The FFV exporters' perception of business relationship quality for retailers is lower than the firms in the food service industry.

\section{Methodology}

Survey design

Ghana was selected as a typical example of countries that supply FFV to Europe. Ghanaian exporters supply to European countries like Germany, the UK, The Netherlands, Italy and Switzerland. In the year 2004 for instance, Ghana supplied about 10 per cent of all fresh pineapples exported into the EU. In addition, the development of the FFV sector in Ghana is more of private sector initiatives. This is unlike many other countries where the development of the FFV sector is dominated by large-scale oriented multinational companies such as Chiquitta, Del Monte, Fyfes and Dole who by their size are able to exercise some countervailing powers in order to reduce unfair business practices with their importers. With the private sector initiatives, firm size in FFV export sector in Ghana varies; ranging from small to large scale. This enabled a representative and fair analysis of the various firm sizes in the industry. Of the 147 export firms identified in the Ghana Fresh Produce Industry Directory 2006 which is official directory compiled by the Ghana Export Promotion Council for all the FFV export firms in Ghana, 101 successful interviews representing about 69 percent response rate was obtained.

Structured questionnaire was used for the data collection. It was designed based on an extensive review of the literature on relationship quality. The questionnaire was pre-tested with four supply chain and alliance specialists and five managers of some exporting firms in Ghana. The participants were asked to comment on the format of the questionnaire including wording, length and order. After each stage, feedback was obtained and the questionnaire was modified.

Two experienced enumerators were recruited and trained to serve as data collectors. The enumerators basically visited the managers who were also the key informants (Phillips, 1981; Mitchell, 1994) in order to increase the response rate. This is based on the evidence that personal visits increase response rates compared to mail surveys. In addition, the enumerators also ensured that all the managers understood the questions in a similar way. The managers were promised to be furnished with the results of the research during the first contact. This contributed to an improvement in the willingness of the managers to participate in the survey. On average, each interview lasted about 50 minutes.

\section{Operationalisation of the constructs}

Relationship quality was measured from the perspectives of the FFV exporters. The approach of measuring relationship quality from the perspective of one actor has been used in the marketing and organisation literature (e.g. Batt, 2003; Schulze et al., 2006; Ceceres and Paparoidamis, 2007). Five-point Likert-scale type questions ranging from $(1=$ strongly disagree, $2=$ disagree, $3=$ partly agree/disagree, $4=$ agree and $5=$ strongly agree) were used to measure these constructs. 
The managers were asked to answer the questionnaire with respect to their main European buyer. A main European buyer refers to a buyer that the supplier considered to be most important in terms of the whole business including quantity, reliability and terms of payment.

In the next stage, the managers were then asked to classify their main European buyers with regard to the three categories. A fourth category representing "other" that might not have been captured was provided. However, the results of the survey indicate that all the 101 European buyers were classified under one of the three categories meaning that no "other" type of buyer category was identified.

In order to put our interpretation of the results of the study into perspective, some controlled variables were also introduced into the model. These variables are factors that may affect the relationship quality of the various groups of buyers. Controlled variables examined are the firm size (measured by the total number of employees) and experience (measured by the number of years in business).

\section{Statistical analyses}

SPSS version 15.0 was the statistical program used for the analyses. To assess the unidimensionality of the relationship quality construct, principal component analyses with Varimax rotation was employed, and all factors with Eigen values above one were extracted. In addition, all factors with factor loadings above 0.5 were retained. The appropriateness of the factor analysis for the scale was tested using the Kaiser-Meyer-Olkin Measure of Sampling Adequacy (KMO-MSA) and the measures fell within the accepted region of greater than 0.5. A reliability test using Cronbach's alpha was used to purify the measurement scale for the relationship quality construct.

In a next step, multivariate analysis of variance (MANOVA) and post-hoc test were conducted in order to test the hypotheses that there is a significant differences in the perceived relationship quality as well as the controlled variables of experience and firm size of the firms that export mainly to retailers on the one hand and each of the firms that export mainly to wholesalers and the food service industry on the other hand.

\section{Results}

\section{Description of the sample}

The results indicate that out of the 101 firms who participated in the survey, 13, 43 and 45 sell mainly to firms in the food service, wholesaling and retailers respectively. The average number of people employed is 56 for firms whose main buyer was classified as food service firm, 106 for firms selling mainly to wholesalers and 80 for firms selling mainly to retailers. The average number of employees is 88 . The experience in the business measured by the number of years in the business indicate that firms in the FFV export business has an average of about nine years in the business with firms selling to the food service, wholesaler and retailers having a mean years of about 12, 14 and 9 years respectively. The descriptive statistics together with the respective standard errors are shown in Table I.

\section{Factor analysis of relationship quality}

The factor analysis showed that the perceived relationship quality of the FFV exporters is unidimensional construct with six items (Gyau and Spiller, 2007a). The relationship quality items together with the corresponding factor loadings are shown

\section{Relationship perception}


JEIM

22,4

\section{8}

Table I.

Descriptive statistics of the exporters in Table II. Together, they explain about 59 percent of the total variance of the construct. The Cronbach's alpha value of 0.861 obtained indicates that the measurement scale has a good reliability (Nunnally, 1978). The results of the factor analysis are shown in Table II.

\section{MANOVA analysis and test of differences}

In order to determine if there is a significant difference in the perception of the relationship quality of the exporters classified according to the type of buyer that they mainly sell to, the multivariate analysis of variance (MANOVA) was used. The MANOVA is an extension of the univariate analysis of variance (ANOVA) to accommodate more than one dependent variable (Ndubisi and Jantan, 2003). The MANOVA was found appropriate in order to simultaneously handle the effects of the relationship quality as well as that of the controlled variables (firm size and experience).

The differences in relationship quality according to whom the exporters sell to were assessed using the Wilks Lambda. The Wilks Lambda was considered as the most appropriate because Hair et al. (1998) have argued that Wilks Lambda examines differences in groups without been concerned with whether they differ on at least one linear combination of dependent variable. In addition, the Wilks Lambda is highly immune to violations of MANOVA assumptions (Ndubisi and Jantan, 2003). The results of the MANOVA for relationship quality as well as the control variables (firm size and experience) and the corresponding univariate measures for each of the independent variables are indicated in Table III.

The MANOVA results indicate that there is a significant effect of the "type of buyer that the exporters' sell to" on the relationship quality, firm size and experience if all these variables are taking together as a group. Table III provides a univariate test for the type of buyer that the exporters' sell to on each of relationship quality, firm size and

\begin{tabular}{lcc}
\hline Type of buyer they sell to & Number of firms exporting to & $\%$ \\
\hline Food service industry & 13 & 12.8 \\
Wholesalers & 43 & 42.6 \\
Retailers & 45 & 44.6 \\
Total & 101 & 100 \\
\hline
\end{tabular}

Relationship quality construct

Factor loadings

The European buyers will not deliberately deceive me

0.829

Considering all my experiences, I am generally very satisfied with the

European buyers

0.804

The business relationships with the European buyers are so good that

I do not think of change

The buyers are honest

0.784

I believe in information provided by the buyers

0.766

The buyers deal with me as expected

0.662
Factor analysis of
relationship quality dimensions

Notes: $\mathrm{KMO}=0.843$, Explained variance $=59.134$ per cent, Cronbach's alpha $=0.861$ 
experience in the business. The results indicate that the firms differ significantly in terms of relationship quality ( $\mathrm{p}$-value $=0.03)$ and experience $(\mathrm{p}$-value $=0.02)$ when they are classified according to whether they sell mainly to retailers, wholesalers or firms in the food service industry. However, the effect of size is not significant (p-value $=0.24)$. Thus, although the firms differ on the first two variables when they are classified according to whom they sell to, the differences are not very strong for the last (i.e. firm size).

In the next stage of the analysis, the mean difference in experience, firm size and the perceived relationship quality of firms that sell mainly to retailers and those that sell to buyers in the other two categories were computed in a post hoc analysis based on the Bonferroni test of differences. The results of the test of differences as exhibited in Table IV indicate that the retailers are evaluated poorly by the firms who export mainly to them compared with how the exporters evaluate wholesalers and food service firms.

\section{Discussions}

The results indicate that the food service firms were perceived better by their suppliers in Ghana in terms of relationship quality compared to retailers. However, a higher level of variability (as shown by standard errors in Table IV in relationship quality for firms in the food service category indicates that the suppliers do not have a uniform perception for the firms categorised under this group. This may be interpreted to mean that European food service industry category of firms may act and behave in a more diverse manner in terms of their relational behaviours compared to wholesalers and the retailers whose variability is lower in terms of how they are perceived by their suppliers from Ghana.

\begin{tabular}{lccccccc}
\hline & & \multicolumn{5}{c}{ Group mean and std error according to } \\
& & \multicolumn{3}{c}{$\begin{array}{c}\text { Eta } \\
\text { type of importer }\end{array}$} \\
Demographic variables & $F$-ratio & Sig & squared & Food & service & Wholesalers & Retailers \\
\hline Perceived relationship quality & 3.57 & 0.03 & 0.03 & $0.45(0.32)$ & $0.16(0.15)$ & $-0.28(0.14)$ \\
Firm size & 1.47 & 0.24 & 0.09 & $56.23(9.13)$ & $106.49(16.91)$ & $80.27(12.32)$ \\
Experience & 4.36 & 0.02 & 0.07 & $11.58(2.36)$ & $14.29(1.41)$ & $9.33(0.91)$
\end{tabular}

Note: $F$-ratio is based on Wilks Lambda

\section{Relationship perception}

449

\begin{tabular}{|c|c|c|c|c|}
\hline Demographic variable & $t$-value & Std error & $p$-value & \\
\hline \multicolumn{5}{|l|}{ Relationship quality } \\
\hline Retailer-wholesaler & -0.45 & 0.21 & 0.08 & \\
\hline Retailer-food service & -0.74 & 0.31 & 0.05 & $\begin{array}{l}\text { Iable IV. } \\
\text { Test of differences in }\end{array}$ \\
\hline Years in business & & & & relationship quality, firm \\
\hline Retailer-wholesaler & -4.95 & 1.69 & 0.01 & size and experience of \\
\hline Retailer-food service & -2.25 & 2.53 & 0.65 & exporters classified \\
\hline Retailer-wholesaler & -26.22 & 19.67 & 0.38 & according to the importer \\
\hline Retailer-food service & -24.04 & 28.96 & 0.69 & category \\
\hline
\end{tabular}


JEIM

22,4

450

The exporters also have a better perception of relationship quality for wholesalers compared to the retailers. Given their lower level of variability, firms that sell mainly to wholesalers may be said to be more homogenous in terms of their perception of relationship quality. Since relationship quality has been associated positively with the actors' ability to establish long-term and collaborative relationships, it might mean that the exporters perceive the other category of buyers to be able to establish better collaborative relationships which may be sustained for a longer period compared to the retailers. In addition, good relationship quality in the form of more trust for instance, may reduce the perceived threat of information asymmetry and opportunistic behaviours (Williamson, 1975) by the exporters signalling that firms that sell mainly to retailers might have to incur higher level of transaction costs such as cost of drawing detail and elaborate contracts, monitoring and enforcement compared to their counterparts who sell to food service firms and wholesalers.

Pair-wise comparison of the firm size (measured by number of employees) indicates that there is no significant difference between the size of firms that sell mainly to the retailers and those who sell to the buyers in other categories. This symptom might imply that those firms that sell mainly to retailers might not be disadvantaged in terms of their size compared to their counterparts who sell to retailers and wholesalers. The above indicate that if the retailers are perceived to have a lower relationship by their suppliers in Ghana compared to those who sell mainly to a buyer in the other categories, then this might not result from the fact that those firms are small and therefore are not able to obtain countervailing powers.

A significant difference between experience (measured by the number of years in business) for the firms that sell mainly to wholesalers and the retailers respectively emphasize the fact that firms that sell directly to retailers are relatively new and less experienced. This perhaps might contribute to the better evaluation of the wholesalers by their suppliers compared to how those that sell to the retailers. This is because firms that have more experience due to their longer period in business might have designed a strategy to deal with their buyers in such a way that they might be satisfied with that relationship. Alternatively, those firms might have dealt with different firms and settled (in terms of satisfaction) with the buyer who provides better terms and conditions. However, it is worth noting that the effect of size on the difference between the experience variable and the type of European importer is weak signalling a word of caution for interpretation of the output.

There is no significant difference between the firms which sell mainly to retailers and the firms in the food service industry in terms of size and experience implying that the differences in the perceived relationship quality observed between these two buyer categories might not be attributed to differences in the size of the firms in the food service industry (which might increase their power position) or their relatively more experience in the business.

In summary, we accept the two hypotheses that were put forward and conclude that Ghana's exporters of FFV have a poor perception of the quality of their relationship with the retailers compared to how buyers in the other categories.

\section{Managerial and policy implications}

In view of the fact that there are differences in the exporters perception of relationship quality of the retailers and the buyers in the other category, it is recommended that 
export firms that would like to do business or form strategic alliances with firms in Europe should use different strategies depending on whether the importer is a retailer or belongs to wholesaler and the food service industry. This is because the exporters' perception of the various categories of European importers might provide an idea about how such buyer groups are likely to act towards their relationships with their business counterparts. This therefore suggests that exporters that deal mainly with importers in the retailing segment for instance, would have to exercise more caution in making relationship specific investments that will yield returns mainly in the longer term. The rationale is that since retailers are perceived by their suppliers to have a lower relationship quality compared to how the others are perceived, they are more likely to put up short-term opportunistic attitudes by exploiting their power position to their advantage, if doing so will enhance their immediate performance without much regard to sustaining the relationship into the future. This means that where possible, the exporters that would want to partner with firms in the retailing segment may have to build in more safeguarding measures such as looking for long-term oriented contracts with the buyers.

Second, where possible, the exporters may also require the retailers to commit some resources when relationship specific investments are involved in order to bind the retailers into the relationship and reduce the tendencies of the retailers to quit the relationship in the short term.

In addition, suppliers who deal with retailers may also adopt strategies in order to improve the relationship. This may include the use of effective negotiations and specific types of influencing behaviours such as persuasion, reasoning and courting of favours with the retailers. Such strategies may create a win-win situation for both the suppliers and the retailers (Mannig and Robertson, 2003).

Moreover, the findings might provide some insights and hints for European business regulatory agencies and anti trust bodies such as the European Commission, fair trade and the competition commissions to better strategise and target their policies which aim to control unfair business practices between suppliers and their buyers. Since the retailers are perceived to have lower business relationship quality, they are more likely to be the ones to resort to unfair business practices. This implies that European Commission and the various national anti-trust enforcement agencies should put more emphasis on the retail segment of the market in order to make rules such as the German Competition Act, the UK Supermarket Code of Practice, the Ireland Grocery Order, and the Galland Law of France to be effective. However, it is worth noting that the effectiveness of the above measure is severely limited by the fact that suppliers are often reluctant to lodge complains to the appropriate authorities even when they have been subjected to unfair treatment and abuse for fear of being blacklisted by the various importers.

Finally, as indicated, the Ghanaian FFV export firms are generally small in size compared to their European large retailers and wholesalers. The situation is even aggravated by the use of buying groups by the European importers. They form these alliances in order to increase their bargaining powers and enjoy economies of scale as these buying alliances create a "near monopsony" situation where many exporters sell to few buying companies. Taking insight from Porter (1980), the exporters will generally be disadvantaged in terms of power balance with the European importers irrespective of which category the buyer belongs to (although there will be differences

\section{Relationship perception}

451 
JEIM

22,4

452

in the levels of the power usage), implying that the buyers might exploit this power and squeeze the exporters profitably. This therefore implies that the Ghanaian exporters can benefit if they form cooperatives or strengthen it where one exists, in marketing their products in the European market. Such a strategy will enable the exporters to reduce the level of power imbalance generally and increase their negotiation powers that will eventually improve their performance.

\section{Conclusion and direction for future research}

In this study, we compared the perceived relationship quality of Ghanaian FFV exporters classified according to their main European buyers. We tested the hypotheses that due to the relatively known undesirable business practices of the retailers, they are more likely to be evaluated poorly in terms of their business relationship quality compared to how the wholesalers and the firms in the food service industry will be evaluated by Ghanaian FFV exporters who sell mainly to them. The statistical analysis supported the above-mentioned hypotheses.

Like many other studies, there are some limitations that must be taken into account in interpreting the results. One is the number of items used to operationalise the relationship quality construct. Some authors have used additional dimensions such as relationship equality opportunism and ethical profile (Leuthesser, 1997; Gassenheimer et al., 1998; Dorsch et al., 1998; Naudé and Buttle, 2000; Schulze et al., 2006) to operationalise the relationship quality construct. This implies that the differences observed between the various groups of importers only relate to the aspects of relationship quality that have been considered in the present research. Future research should therefore include more dimensions of the relationship quality in order to provide a more holistic view of the relationship quality construct. In addition, future research should also measure the relationship quality from the perspective of the European importers. This will enable us to know the other side of the story.

Finally, as one of the first studies to explicitly compare the relationship quality of the various categories of buyers in the food supply chains, future research should use this as a basis to replicate the results in other areas of the food supply chain before the results can be generalized. Until then, the results and the conclusions from this study may be taken as tentative.

\section{References}

Anderson, E. and Weitz, B.A. (1989), "Determinants of continuity in conventional industrial channel dyads”, Marketing Science, Vol. 8 No. 4, pp. 310-23.

Anderson, J.C. and Narus, J.A. (1990), “A model of distributor firm and manufacturer firm working partnerships", Journal of Marketing, Vol. 54 No. 1, pp. 42-58.

Baker, M.J. (1995), “Marketing - philosophy or function?”, in Baker, M.J. (Ed.), Encyclopaedia of Marketing, Routledge, London, pp. 1003-18.

Batt, P.J. (2003), "Building trust between growers and market agents", Supply Chain Management, Vol. 8 No. 1, pp. 65-78.

Berry, L. and Parasuraman, L. (1995), "Relationship marketing of services - growing interest: emerging perspectives", Journal of Academic Marketing Science, Vol. 23 No. 4, pp. 236-45.

Ceceres, R.C. and Paparoidamis, N.G. (2007), "Service quality, relationship satisfaction, trust commitment and business-to-business loyalty", European Journal of Marketing, Vol. 41 No. 7/8, pp. 836-67. 
Cox, A., Sanderson, J., Watson, G. and Lonsdale, C. (2003), "The role of incentives in buyer-supplier relationships: industrial cases from a UK study", Proceedings of the 19th Annual IMP Conference, Lugano, Switzerland, September 4-6, 2003.

Crosby, L.A., Evans, K.R. and Cowles, D. (1990), "Relationship quality in services selling: an interpersonal influence perspective", Journal of Marketing, Vol. 54 No. 3, pp. 68-81.

Dobson, P. (2005), "Exploiting buyer power: lessons from the British grocery trade", Anti Trust Law Journal, Vol. 72 No. 2, pp. 529-42.

Dorsch, M.J., Swanson, S.R. and Kelly, S.W. (1998), "The role of relationship quality in the stratification of vendors as perceived by customers", Journal of the Academy of Marketing Science, Vol. 26 No. 2, pp. 128-42.

Dwyer, R.F., Schurr, P.H. and Oh, S. (1987), "Developing buyer-seller relationships”, Journal of Marketing, Vol. 51 No. 2, pp. 11-27.

Ellram, L. and Cooper, M. (1993), "Supply chain management, partnerships, and the shipper-third party relationship", International Journal of Logistics Management, Vol. 2 No. 1, pp. 1-10.

Emerson, R.M. (1962), "Power-dependence relations", in Olsen, M.E. (Ed.), Power in Societies, Macmillan Publishing, New York, NY, pp. 44-53.

Fearne, A. and Hughes, D. (1999), "Success factors in the fresh produce supply chain: insights from the UK", Supply Chain Management, Vol. 4 No. 3, pp. 120-8.

Food Institute (1999), The Food Institute Report, Food Institute, Fair Lawn, NJ.

Ford, D. (1994), "Developing a relationship strategy", Proceedings of the 2nd International Colloquium on Relationship Marketing, Cranfield School of Management, Cranfield Umiversity, 13-14 November.

Ganesan, S. (1994), "Determinants of long-term orientation in buyer-seller relationships", Journal of Marketing, Vol. 58 No. 2, pp. 1-19.

Garbarino, E. and Johnson, M.S. (1999), "The different role of trust, satisfaction and commitment in customer relationships", Journal of Marketing, Vol. 63 No. 2, pp. 70-87.

Gassenheimer, J.B., Houston, F.S. and Davis, C.J. (1998), "The role of economic value, social value, and perception of fairness in inter-organisational relationships retention decision", Journal of the Academy of Marketing Science, Vol. 26 No. 4, pp. 322-37.

Gummesson, E. (1996), "Relationship marketing and the imaginary organisation: a synthesis", European Journal of Marketing, Vol. 30 No. 2, pp. 31-44.

Gyau, A. and Spiller, A. (2007a), "The role of organisational culture in modeling buyer-seller relationships in the fresh fruit and vegetable trade between Ghana and Europe", African Journal of Business Management, Vol. 1 No. 8, pp. 218-29.

Gyau, A. and Spiller, A. (2007b), "Determinants of trust in the international fresh produce business between Ghana and Europe", International Business Management, Vol. 1 No. 4, pp. 104-11.

Hair, J.F. Jr, Anderson, R.E., Tatham, R.L. and Black, C.K. (1998), Multivariate Analysis, 5th ed., Prentice-Hall, Upper Saddle River, NJ.

Jarvelin, A. and Lehtinen, U. (1996), "Relationship quality in a business-to-business service context”, in Edvardson, B.B., Johnson, S.W. and Scheung, E.E. (Eds), QUIS 5 Advancing Service Quality: A Global Perspective, Warwick Printing, Lethbridge, pp. 243-54.

Kim, W.G. and Cha, Y. (2002), “Antecedents and consequences of relationship quality in hotel industry", International Journal of Hospitality Management, Vol. 21 No. 4, pp. 321-38.

\section{Relationship perception}

453 
JEIM

22,4
Kim, W.G., Lee, Y.K. and Yoo, Y.J. (2006), "Predictors of relationship quality and relationship outcome in luxury restaurants", Journal of Hospitality and Tourism Research, Vol. 30 No. 2, pp. 143-69.

Kumar, N. (1996), "The power of trust in manufacturer retailer relationships”, Harvard Business Review, Vol. 74 No. 6, pp. 92-106.

Kumar, N., Scheer, L.K. and Steenkamp, J.B.E. (1998), "Inter-dependence, punitive capability and the reciprocation of punitive actions in channel relationships", Journal of Marketing Research, Vol. 35 No. 2, pp. 225-35.

Leuthesser, L. (1997), "Supplier relational behaviour: an empirical assessment", Industrial Marketing Management, Vol. 26 No. 3, pp. 245-54.

Mannig, T. and Robertson, M. (2003), "Influencing and negotiation skills: some research and reflections - Part 1: Influencing strategies and styles", Industrial and Commercial Training, Vol. 35 No. 1, pp. 11-15.

Mitchell, V.W. (1994), "Using industrial key informants: some guidelines", Journal of the Marketing Science Society, Vol. 36 No. 2, pp. 139-44.

Moorman, C., Zaltman, G. and Desphandé, R. (1992), "Relationship between providers and users of market research: the dynamics of trust between and within organisations", Journal of Marketing Research, Vol. 29 No. 3, pp. 314-28.

Morgan, R.M. and Hunt, S. (1994), "The commitment-trust theory of relationship marketing", Journal of Marketing, Vol. 58 No. 3, pp. 20-38.

Naudé, P. and Buttle, F. (2000), “Assessing relationship quality", Industrial Marketing Management, Vol. 29 No. 4, pp. 351-61.

Ndubisi, N.L. and Jantan, M. (2003), "Malaysian entrepreneurs and strategic use of information technology", Malaysian Management Review, Vol. 38 No. 1, pp. 32-42.

New, S.J. (1996), “A framework for analyzing supply chain improvement”, International Journal of Operations \& Production Management, Vol. 16 No. 4, pp. 19-34.

Nunnally, J.C. (1978), Psychometric Theory, 2nd ed., McGraw-Hill, New York, NY.

Patterson, M.P. and Richards, T.J. (2000), "Produce marketing and retail buying practices", Review of Agricultural Economics, Vol. 22 No. 1, pp. 160-71.

PFID (2003), "Ghana public-private partnership food industry development program: analysis of the Ghanaian fresh fruits and vegetable industry”, USAID Mission Report, Washington, DC.

Phillips, L.W. (1981), "Assessing measurement error in key informant reports: a methodological note on organisational analysis in marketing", Journal of Marketing Research, Vol. 18 No. 4, pp. 395-415.

Porter, M.E. (1980), Competitive Strategy: Techniques for Analyzing Industries and Competitors, Free Press, New York, NY.

Pritchard, M.P., Havitz, M.E. and Howard, D.R. (1999), "Analyzing the commitment loyalty link in service context”, Journal of Academy of Marketing Science, Vol. 27 No. 3, pp. 333-48.

Rokkan, A.L. and Haughland, S.A. (2002), "Developing relational exchange: effectiveness and power", European Journal of Marketing, Vol. 36 No. 1, pp. 211-30.

Schulze, B., Spiller, A. and Wocken, C. (2006), "Relationship quality in agri-food chains: supplier management in the German pork and dairy sector", paper presented at the 16th Annual World Forum and Symposium, Agribusiness, Health and Nutrition, IAMA Conference, Buenos Aires, Argentina, June 10-15 2006.

Takane, T. (2004), "Small-holders and non-traditional exports under economic liberalization: the case of pineapples in Ghana”, African Studies Monograph, Vol. 25 No. 1, pp. 29-43. 
Thibaut, J.W. and Kelly, H.H. (1959), The Social Psychology of Groups, Wiley, New York, NY.

Vadarajan, P.R. and Cunningham, M.H. (1995), "Strategic alliances: a synthesis of conceptual foundations", Journal of the Academy of Marketing Science, Vol. 23 No. 4, pp. 305-20.

Williamson, O.E. (1975), Markets and Hierarchies: Analysis and Anti-Trust Implications, Free Press, New York, NY.

Wong, A. and Sohal, A. (2002), "An examination of the relationship between trust, commitment and relationship quality", International Journal of Retail \& Distribution Management, Vol. 30 No. 1, pp. 34-50.

Wray, B., Palmer, A. and Bejou, D. (1994), "Using neural network analysis to evaluate buyer-seller relationships", European Journal of Marketing, Vol. 28 No. 10, pp. 32-48.

\section{Corresponding author}

Amos Gyau can be contacted at: amosgyau@yahoo.com

\section{Relationship perception} 455

To purchase reprints of this article please e-mail: reprints@emeraldinsight.com Or visit our web site for further details: www.emeraldinsight.com/reprints 